L. G. Matveyeva ${ }^{\text {a) }}$, Y. V. Mikhalkina ${ }^{\text {a) }}$, O. A. Chernova ${ }^{\text {a) }}$

a) Southern Federal University

\title{
THE POSSIBILITIES OF THE RUSSIAN REGIONS CAPACITY INCREASING UNDER THE EXTERNAL THREATS
}

Managing of using and developing the Russian regions potential under the terms of economic sanctions from foreign countries require prior modeling of the results of decisions made to identify the most signif-

${ }^{1}$ (C) Matveyeva L. G., Mikhalkina Y. V., Chernova O. A. Text. 2015. 
cant areas of management actions. The main aim of the paper is to study the possibilities of cognitive modeling methods in the process of assessing the consequences of external threats to regional economies and the subsequent generation of solutions that are foreground in the terms of regions total potential increasing. On the basis of developed cognitive model, the analysis of interconnected impulsive processes in managing the region's economic potential was made, which demonstrates the possibilities of using this model to predict the possible trends of development of the situation within the implementation of the specific management decisions. Sequence of the procedures conducted in the framework of the model allows to define the priority and the importance of the impacts on the development of the region's internal potential under the external threats. As well as to assess the necessity and adequacy of the stimulating and regulatory management measures application, due to the changes of the key factor of the model in order to prevent undesirable changes of the target factors and, in contrary, to improve them. Presented tool is universal and can be adapted to the specific regional conditions and specific "threats."

Keywords: economic potential of the region, the cognitive model, external threats, impulse modeling

The ongoing processes of the progressive escalation of the economic pressure on Russia by the United States and several European countries, caused by the present political situation in Ukraine, along with the questions of assessing the possible damage that may be incurred by the national economy, also affect the important problem of identifying of the economic growth's potential in the regions under the influence of the economic sanctions. The most likely external threats from the Western countries are:

- embargo (restrictions) on the import of the strategic goods and resources to Russia: pharmaceuticals, food products, technologies, and equipment, etc.;

- establishing of an embargo on the energy resources supplied from Russia;

- reduction of the investment into Russian economy;

- freezing of the of the Russian investors' deposits, including state-owned companies.

It is necessary to note that the vulnerability to external sanctions of the Russian economy, as it was noted by S.Y. Glazyev during the Moscow Economic Forum held on 26-27 March 2014, mostly caused by the fact that the strategic orientations of its development in the recent years have been aimed at achieving the goals of world globalization to the prejudice of domestic state development goals. Definitely, the disruption of the economic ties between Russia and the West countries in the short term can lead to the significant financial and economic losses. At the same time, on the background of the external threats, which are another signal of the need to change the course of export-oriented development, Russia has an opportunity to develop the fundamentally new paradigm of the development, that is aimed to the realization of the import substitution strategy by building and effective implementation of the internal potential of Russian regions. It appears that the main features of its capacity in the framework of this strategy are related primarily to the gradual Russian economy reorientation to non-commodity model of development and can be expressed as follows:

- the growth of intellectual rent, because the non-commodity manufacturing leads to the growth of human potential, "creates the demand for the qualified and creative staff, and the conditions for the emergence and implementation of the innovations, the conditions for technological, social, demographic progress, the request to improve the human environment" [2];

- the growth of the innovative incomes and added value in knowledge-intensive industries;

- the improvement of the commercialization level of the national scientific research, and of the scientific research results by reducing the proportion of foreign equipment and technologies;

- the inflow of the national business investments into the Russian economy as the result of increased risk of freezing deposits abroad.

It is difficult to evaluate the impact of economic sanctions of the certain types of external threats on changing of the economic potential of the regions. This can be explained by the existing domination of the significant amount of non-quantifiable regularities. Simultaneously, the individual effects which are arising as the result of the economic restrictions introduction, are quantifiable, that allows to integrate into a single model the emerging causal relationships, to identify current problem's areas and the most vulnerable sectors of the regional economy due to the changes in environmental factors, to develop appropriate management impacts on the elimination of the negative effects and using the opportunities provided.

We emphasize that the paradigm of the management of the national economy development in terms of the risk of possible economic sanctions introduction should be based on understanding 
that such sanctions are not only the threats, but also the resources for the further development. This concept of the external threats perception should be based on a new regional economic policy in Russia, which is focused on modernization and innovative development of its non-oil economy sector. At the same time, it is crucial to identify priorities for the state influence on the economic potential within individual areas according to the specific regional determinants.

One of the methods that allow fixing such influence in the form of a formal model is the cognitive approach which is used, as well known, in studies of semistructured systems and processes, but this method is not yet widespread in the practice of regional management.

The methodology of this research is based on the papers by Atkin R., Axelrod R., Eden C., Legrand J., Warren K. [3, 4, 5, 6, 7] Gorelova G.V., Kakatunova T.V., Zhuzhginoya I.A., Kochkarova A.A., Salpagarova M.B. [8, 9, 10, 11, 12, 13, 14], which show the possibilities of using the cognitive modeling approach for regional systems, considerable attention is paid to the modeling methodology, but the capabilities of the model are not demonstrated in them. In contrast of the named researches, this research demonstrates the practical use of the cognitive modeling techniques as a base of making specific management decisions.

The research was conducted according to the following stages of cognitive modeling:

- formalization of the goal setting process;

- construction of the cognitive map, which is based on the system structuring;

- impulse modeling;

- interpretation of the modeling results.

For the construction of the cognitive map, the next concepts of the system-functional model have been highlighted.

Public authorities is highlighted, including the regional offices of the federal government and the regional authorities of the subjects of Russian Federation. In the context of import restrictions of the high-tech products the public authorities by the regulatory impacts can influence on the development of the real sector of the region economy significantly, including its science and technology base, by setting the priorities in the budget allocation, determining the measures of the state support.

Institutional environment of the region is highlighted, because the state of the institutional environment determines the efficiency of investment in the real economy sector, as well as the forms and technologies of cooperation between business and research organizations.
Another group of factors, which have influence on the region internal potential associates with the functioning of the real economy sector, the level of which is influenced by the volume and nature of the investment, as well as the innovations market, and besides the real sector companies play the leading role in the formation of the supply of innovative products and technologies. Investment activity of economic entities is largely determined by ongoing regional financial and credit policies, and the development of the innovation market is inextricably linked to the level of scientific and technical potential of the territory.

It also seems appropriate to mark in the cognitive model the block of regional risks. This is connected to the fact that the possibilities of the regional potential increasing, especially in the innovative sphere and modernization of the real sector economy, directly correspond to the specific regional factors and the conditions of development. In this case, the functional connections between the certain types of regional risks and other concepts of a cognitive map can be both direct and reverse. Thus, the level of innovation and investment activity of companies is largely determined by the level of environmental uncertainty of business development in the region. On the other hand, the implementation of commercial investment projects (due to the systemic character of their functions) leads to increasing of the functional stability of the regional system, and to the reduction of the regional risks level.

In general we can note that the regional determinants that contribute the specificity of influence and provide opportunities for the economic development of the region, which are administered by economic sanctions, occur within the characteristics of all these concepts of the cognitive map.

The list of indicators, which characterize the subject area of the research, as well as the functional dependencies of vertices of the cognitive map, is shown in the Table 1. This list is not exhaustive and may be supplemented and adjusted by considering the specific regional factors, as well as research purposes.

The purpose of the developed system-functional model is to study the possibilities of the region internal capacity-building in terms of the adoption of the economic sanctions through control actions by public authorities on the basis of determining the nature, strength and scale of emerging positive and negative effects. The target factors of the model are distinguished by the internal potential of the region, the real sector of 
Characteristics of problem situations in the regional economy, which are defining the cognitive model

\begin{tabular}{|c|c|c|}
\hline $\begin{array}{l}\text { «Top» of the cognitive } \\
\text { map }\end{array}$ & Factors and indicators & $\begin{array}{l}\text { Functional } \\
\text { dependence }\end{array}$ \\
\hline $\begin{array}{l}\text { Total internal capacity } \\
\text { of the region }\end{array}$ & $\begin{array}{l}\text { the gross regional product; } \\
\text { the level of employment; } \\
\text { incomes and costs of the regional budget; } \\
\text { the proportion of the own incomes of the consolidated budget of the } \\
\text { region in its total costs; } \\
\text { innovative potential; } \\
\text { investment potential; } \\
\text { capitalization of resource potential }\end{array}$ & $X_{1}, x_{1}^{i} \in X_{1}, i=\overline{1, n_{1}}$ \\
\hline Public authorities & $\begin{array}{l}\text { regional policy; } \\
\text { orientation on the support of the real sector of economy; } \\
\text { target programs for supporting the development of the real sector of the } \\
\text { economy; } \\
\text { the presence of government guarantees for lending the projects of the real } \\
\text { economy sector; } \\
\text { the presence of the public-private partnership projects in the real economy } \\
\text { sector }\end{array}$ & $X_{2}, x_{2}^{i} \in X_{2}, i=\overline{1, n_{2}}$ \\
\hline $\begin{array}{l}\text { Institutional } \\
\text { environment }\end{array}$ & $\begin{array}{l}\text { the legal regulation; } \\
\text { the development of innovation infrastructure; } \\
\text { activities of the institutions for the development; } \\
\text { other indicators }\end{array}$ & $X_{3}, x_{3}^{i} \in X_{3}, i=\overline{1, n_{3}}$ \\
\hline $\begin{array}{l}\text { Financial and credit } \\
\text { environment }\end{array}$ & $\begin{array}{l}\text { forms and technologies of financing the projects of modernization in the } \\
\text { real economy sector; } \\
\text { the level of development of the infrastructure financing into the innovative } \\
\text { projects; } \\
\text { indicators of venture investment; } \\
\text { availability of the project financing system }\end{array}$ & $X_{4}, x_{4}^{i} \in X_{4}, i=\overline{1, n_{4}}$ \\
\hline Innovations & $\begin{array}{l}\text { innovative activity of the enterprises; } \\
\text { sectorial structure of the innovation activity sphere }\end{array}$ & $X_{5}, x_{5}^{i} \in X_{5}, i=\overline{1, n_{5}}$ \\
\hline Investment & $\begin{array}{l}\text { the total volume of the investments in the region; } \\
\text { the share of the residents' investments into the regional economy in their } \\
\text { total value; } \\
\text { sectorial structure of investments; } \\
\text { the volume of investments into the innovation }\end{array}$ & $X_{6}, x_{6}^{i} \in X_{6}, i=\overline{1, n_{6}}$ \\
\hline $\begin{array}{l}\text { The real sector of } \\
\text { economy }\end{array}$ & $\begin{array}{l}\text { demand and supply; } \\
\text { capacity and saturation of the regional market; } \\
\text { the structure of industrial markets; } \\
\text { the share of exports and imports } \\
\text { the share of innovative produced products } \\
\text { the number of advanced technologies used }\end{array}$ & $X_{7}, x_{7}^{i} \in X_{7}, i=\overline{1, n_{7}}$ \\
\hline $\begin{array}{l}\text { Scientific and technical } \\
\text { potential }\end{array}$ & $\begin{array}{l}\text { the change in the intellectual rent; } \\
\text { the share of high-tech industry; } \\
\text { the level of the national R \& D commercialization; } \\
\text { the number of national patents and engineering } \\
\end{array}$ & $X_{8}, x_{8}^{i} \in X_{8}, i=\overline{1, n_{8}}$ \\
\hline Regional risks & $\begin{array}{l}\text { economic; } \\
\text { investment; } \\
\text { legislative; } \\
\text { social; } \\
\text { environmental } \\
\end{array}$ & $X_{9}, x_{9}^{i} \in X_{9}, i=\overline{1, n_{9}}$ \\
\hline Economic sanctions & $\begin{array}{l}\text { embargo (restrictions) on the import of the strategic goods and resources to } \\
\text { Russia: pharmaceuticals, food products, technologies and equipment, etc.; } \\
\text { establishing of an embargo on the energy resources supplied from Russia; } \\
\text { reduction of the investment into Russian economy; } \\
\text { freezing of the of the Russian investors' deposits, including state-owned } \\
\text { companies }\end{array}$ & $X_{10}, x_{10}^{i} \in X_{10}, i=\overline{1, n_{10}}$ \\
\hline
\end{tabular}




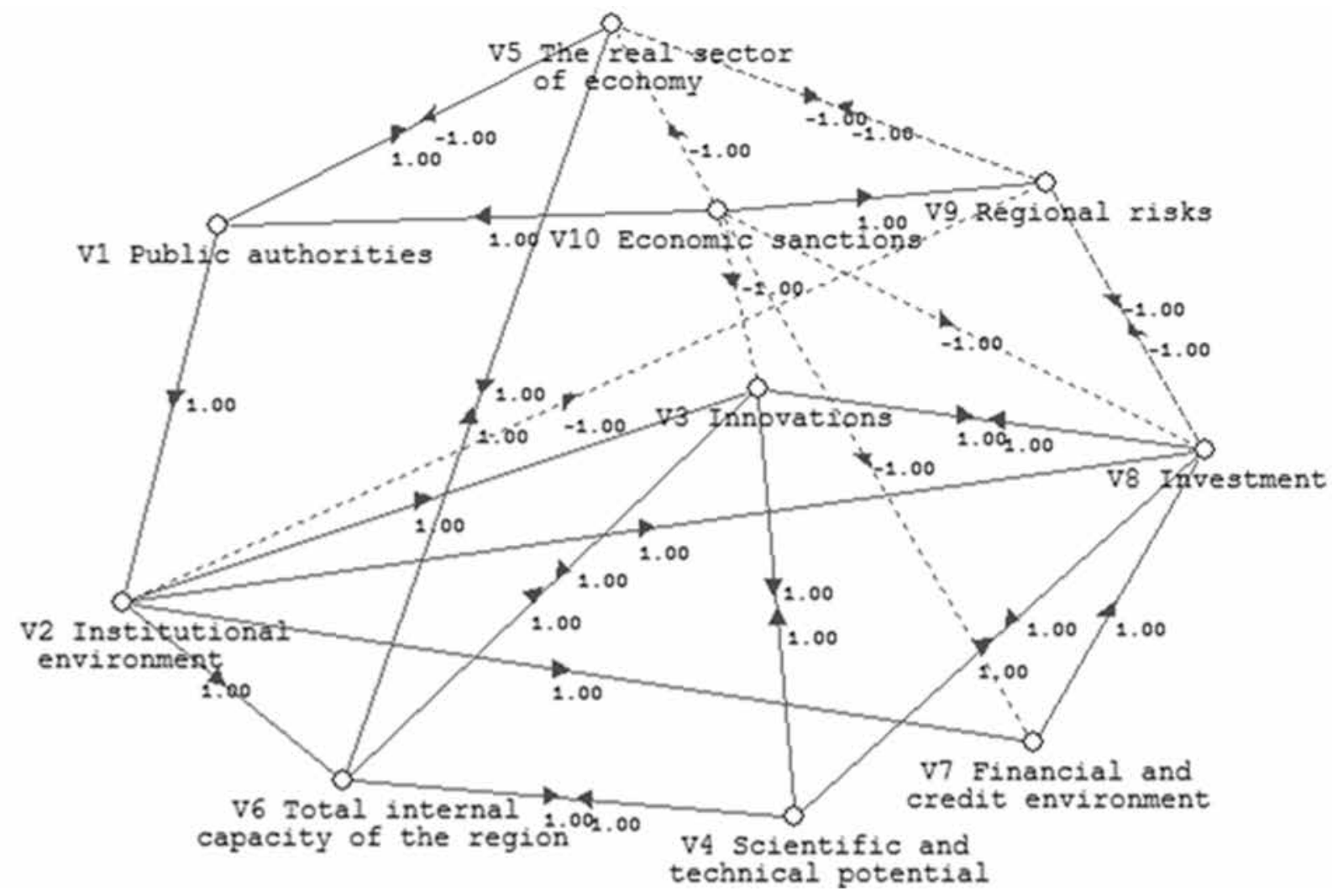

Fig. 1. Cognitive map

economy and innovation, due to their priority in the transition of the Russian economy to the nonoil model, which is based on the capitalization of the domestic resources capacity in the region, as well as on the goals of innovatization and modernization of its non-oil sector.

The proposed model does not attempt the optimization of the target factors such as maximizing the internal potential of the region. The main challenge is to solve the problems of necessity and appropriateness of the application of any stimulating and regulatory management impacts due to the changes in key factor of the model - "the introduction of economic sanctions by foreign countries" to prevent unwanted changes in target factors, but on the contrary, to contribute its improvement.

The cognitive map, which presents the strongest dependence of analyzed processes, is shown in the Figure 1. The model was built by using the program system of cognitive modeling [15].

On the map the solid arrows indicate the "direct" links between the next factors: the signal increase on the one top leads to the response signal increase on the other and vice versa, the decrease of the signal on the one top leads to the response decrease on the other. The dotted line arrows indicate the "reverse" links, when the signal increasing on one top leads to the response signal decrease on the other and vice versa.
The constructed cognitive map allows to conduct the analysis of pulsed processes, which allows to predict the possible development of the situation in the region under the influence of the economic sanctions. The pulse process model assumes that the signal, which is proceeded to one or more tops and extended in the form of the chain generates a pulse process, amplifying or attenuating [16].

The matrix of adjacent configuration $(R)$ of the proposed cognitive map would be as follows (Table 2).

The modeling of the economic sanctions impact on the internal potential of the region can be conducted by pulses. For this to the top of "Economic sanctions" was given some pulse +1 , which actualizes the whole system of indicators. It is assumed that the initial values of the all tops are equal to zero. The rule of the distribution of the process of disturbances on the graph can be presented as follows [10]:

$$
x_{i}(n+1)=x_{i}(n)+\sum_{j=1}^{k-1} \lambda_{j i} \omega_{j i}\left[x_{j}(n+1)-x_{j}(n)\right],
$$

where $x(n), x(n+1)-$ the values of the indicator on the top $V$ within the simulation steps at the moment $t=n$ and follows it $t=n+1, \lambda_{i j}$, - coefficient, which characterizes the sign «+» or «-», $\omega_{i j}$, the coefficient, which characterizes the influence degree of the top $V_{j}$ parameter on the top $V_{i}$ pa- 
The matrix of adjacent configuration

\begin{tabular}{|c|c|c|c|c|c|c|c|c|c|c|c|}
\hline & & $V 1$ & $V 2$ & $V 3$ & $V 4$ & $V 5$ & $V 6$ & $V 7$ & $V 8$ & $V 9$ & $V 10$ \\
\hline & $V 1$ & 0 & 1 & 0 & 0 & 1 & 0 & 0 & 0 & 0 & 0 \\
\hline & $V 2$ & 0 & 0 & 1 & 0 & 0 & 1 & 1 & 1 & -1 & 0 \\
\hline & $V 3$ & 0 & 0 & 0 & 1 & 0 & 1 & 0 & 1 & 0 & 0 \\
\hline & $V 4$ & 0 & 0 & 1 & 0 & 0 & 1 & 0 & 1 & 0 & 0 \\
\hline$R=$ & $V 5$ & -1 & 0 & 0 & 0 & 0 & 1 & 0 & 0 & -1 & 0 \\
\hline & $V 6$ & 0 & 0 & 1 & 1 & 1 & 0 & 0 & 0 & 0 & 0 \\
\hline & $V 7$ & 0 & 0 & 0 & 0 & 0 & 0 & 0 & 1 & 0 & 0 \\
\hline & $V 8$ & 0 & 0 & 1 & 1 & 0 & 0 & 0 & 0 & -1 & 0 \\
\hline & $V 9$ & 0 & 0 & 0 & 0 & -1 & 0 & 0 & -1 & 0 & 0 \\
\hline & $V 10$ & 1 & 0 & -1 & 0 & -1 & 0 & -1 & -1 & 1 & 0 \\
\hline
\end{tabular}

rameter (determined by an expert way or by using statistical methods).

The set of pulse processes at all the tops suggests the conclusion of the possible scenarios of the system development. To do this, on the top graph $V 10$ «Economic sanctions" there was given some pulse $+1(q 10=+1)$.
We note that in solving the problem of forecasting of the possible situation changes, which characterizes the state of the regional economy under the impact of economic sanctions, modeling cycles, which are indicated on the $x$-axis, must be tied to the time. In this research this problem has not been set. It is only matter of the description of the possible development trends of the analyzed situation. The axis of ordinates denotes the changes proportions of the initial pulse +1 . In the case of using of the quantitative descriptions of the relationships between the tops on the $y$-axis it is possible to reflect the absolute variations of the indicator.

Figure 4 shows the results of possible situation development in the economic system of the region in terms of the economic sanctions within the sufficiently simplified conditions. However, obtained model trends in the whole do not contradict to those observed. Thus, the introduction of economic sanctions leads to undesirable and, starting from the second modeling cycle - to the rapid

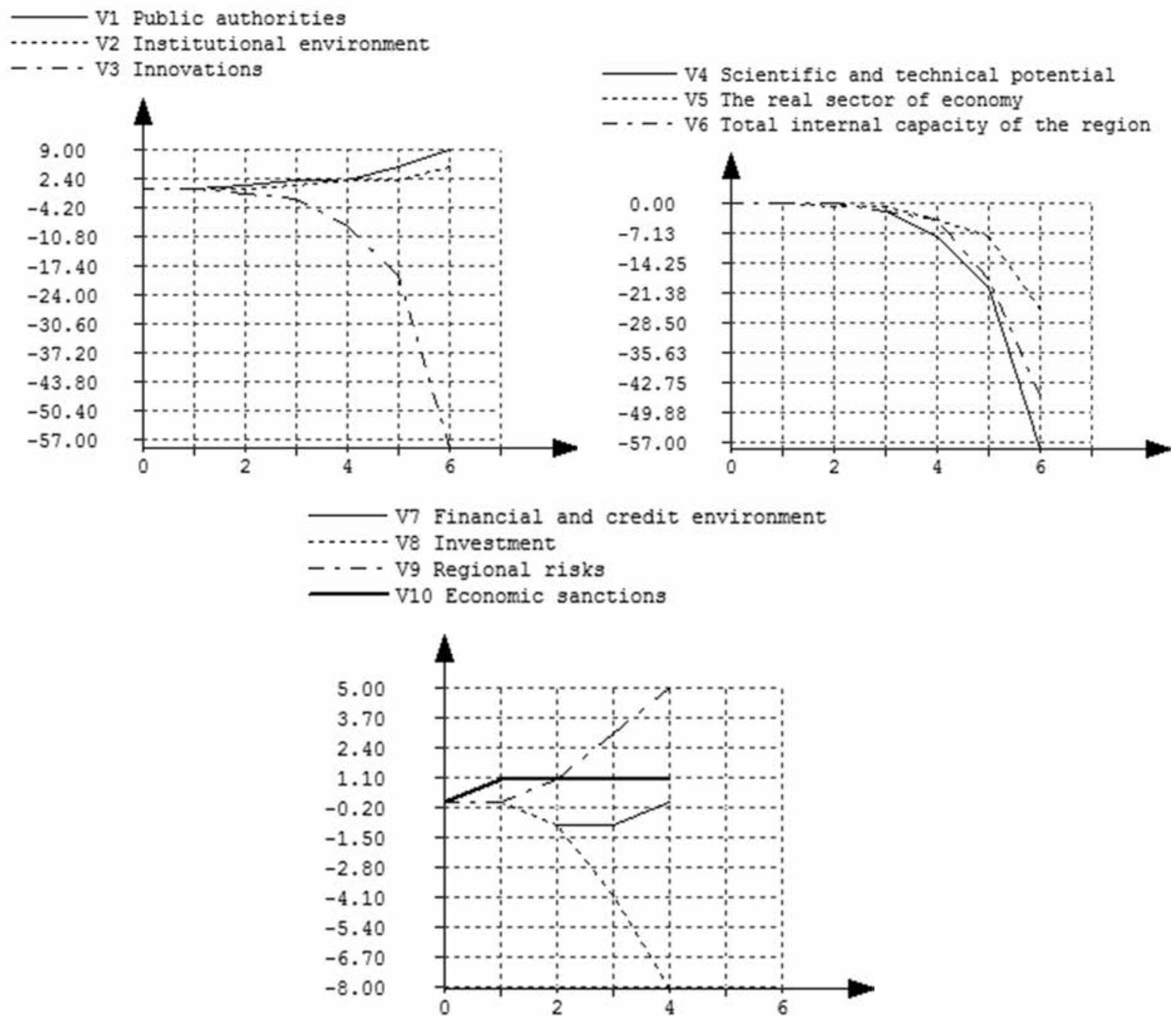

Fig. 2. the Script 1: increasing of the economic sanctions $(q 10=+1) ; Q 1=\{q 1=0,0,0,0,0,0,0,0,0,+1\}$ 

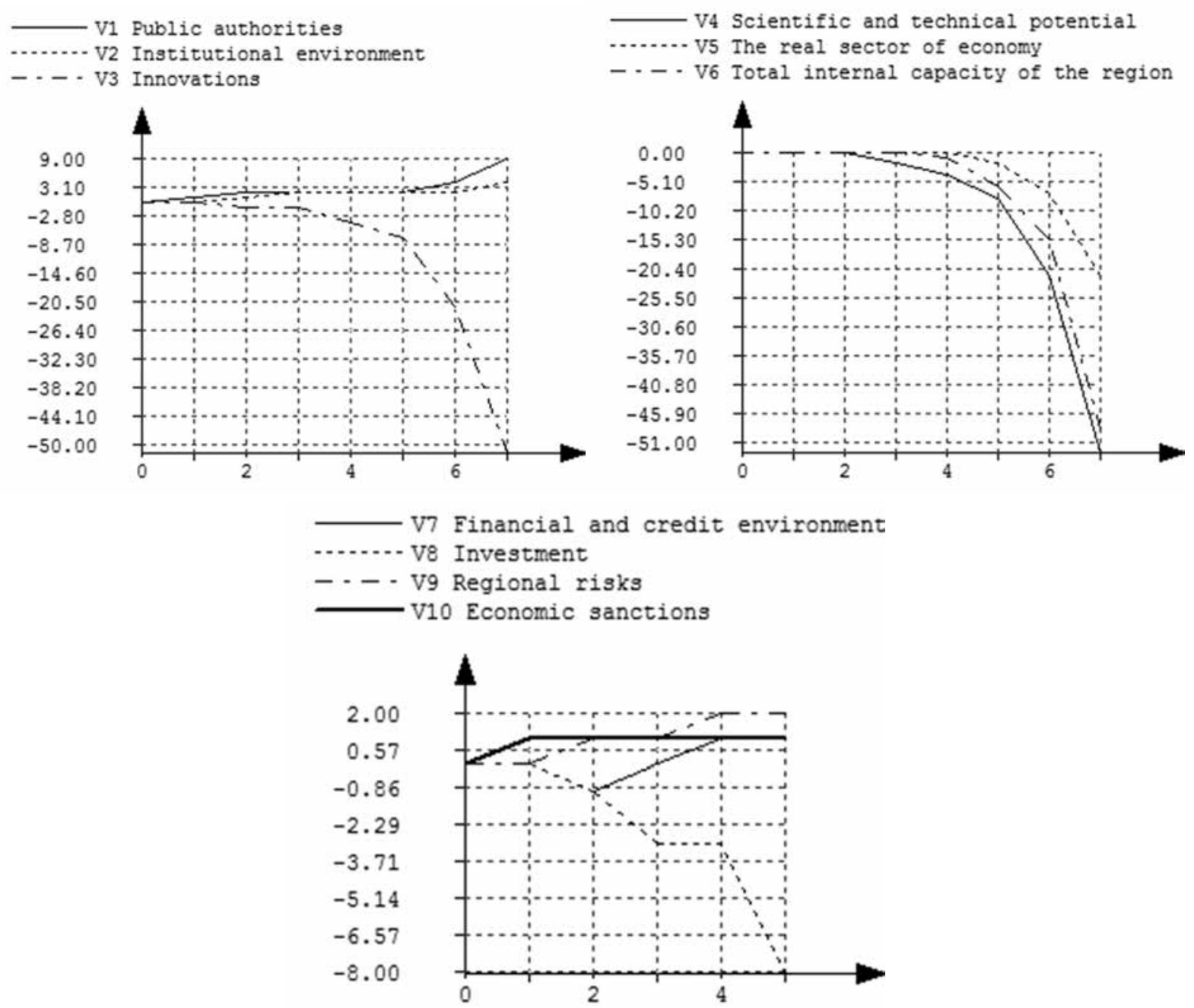

Fig. 3. Script №2: the increase of the economic sanctions $(q 10=+1)$ and the response impact of public authorities $(q 1=+1) ; Q 2=$ $\{q 1=+1,0,0,0,0,0,0,0,0,+1\}$

deterioration of the indicators of the region internal potential, as well as to the growth of regional risks. Simultaneously with the same cycle of modeling the trend of the authorities and management activity begins to develop, improvement of the institutional environment, but with the rates, that are not comparable with the rates of the internal regional capacity decline because of their low rates.

Let us consider to what will lead the introduction of the response management actions from the state on using and increasing of the internal capacity of the region, as well as of the response effects of one of its key components - financial and credit institutions.

Figure 5 shows the results of computational experiment that reveals how will change the internal potential of the region under the influence of threat "Economic sanctions" $(q 10=+1)$ and response impact of public authorities $(q 1=+1)$.

Obviously, that the target-oriented state influence on the increasing of the principal compo- nents of the internal potential of the area will allow the significant reduction of the regional risks level, as well as will have a positive impact on the state of the financial and credit environment. In addition, the indicator "investment" will significantly slow down that, according to recent official statistics, is characterized by negative growth. It should be also specifically emphasized that despite of the fact that the whole trend of declining of the key components of the Russian regions internal potential under the influence of economic sanctions will not change, but its rates will fall due to the target regulatory and management influences from the public authorities of the territories.

Regarding the influence of the response impact of key components of the regions internal potential, in particular the financial and credit environment, on the introduction of economic sanctions, in itself a change of state of this component does not lead to noticeable changes in the value of the region internal potential. Obviously in order to 

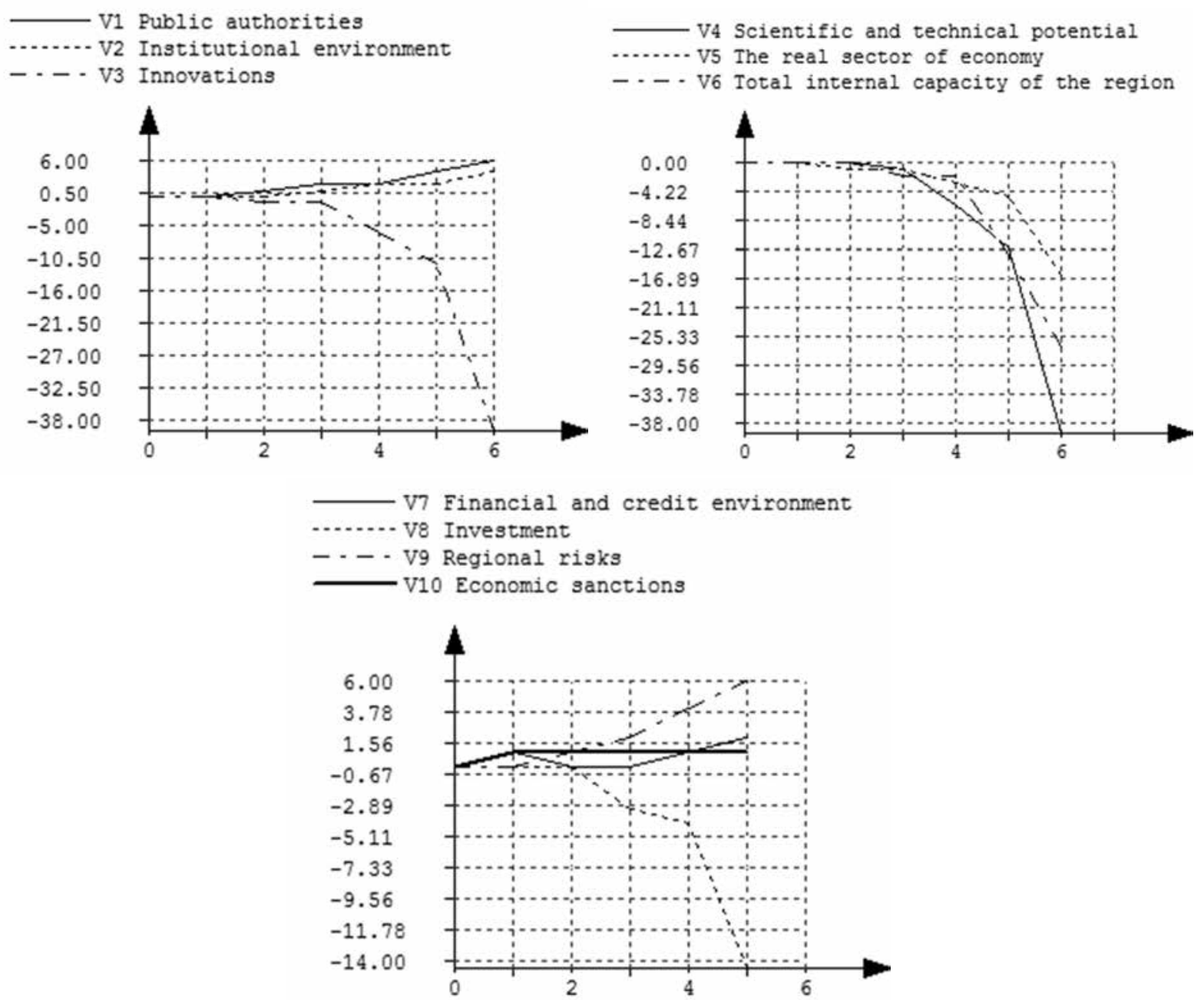

Fig. 4. Script № 3: the increase of the economic sanctions $(q 10=+1)$ and the response impact of the financial and credit environment $(q 7=+1) ; Q 3=\{q 1=0,0,0,0,0,0,+1,0,0,0\}$

manifest this effect, it is necessary to change the complex set of regional factors.

Figure 6 shows the change of the internal potential of the region under the influence of the threat "Economic sanctions" ( $q 10=+1)$ and the response impact of the financial and credit environment $(q 7=+1)$ (figure 7).

These examples merely illustrate the possibilities of using of the cognitive models in order to develop solutions which will be most important for regional development. Obviously that for more adequate predict scenarios of the situations development it is necessary to expand the cognitive map by increasing the number of considered "tops", as well as to specify the connections between them.
Thus, the presented tool demonstrates the possibilities of using the analysis of pulse processes in the framework of the cognitive models in order to predict the possible trends of developments in the economic system of the region in terms of the external threats within the realization of the specific management actions. This allows to determine the priority and importance of the effects on the internal potential development of the region, to justify and to estimate the necessity and the adequacy of the certain management decisions adoption not only to prevent unwanted changes in target factors, but rather to improve them. Proposed tool is universal and can be adapted to specific regional conditions and specific "threats".

\section{References}

1. Materialy Moskovskogo ekonomicheskogo foruma [Materials of the Moscow Economic Forum]. Mokovskiy ekonomicheskiy forum [The Moscow Economic Forum]. Available at: http://me-forum.ru/presenters/ (date of access: 20.04.2014).

2. Obrashchenie initsiatorov Moskovskogo ekonomicheskogo foruma ot 27.03.2014 [Appeal of initiators of Moscow Economic Forum on 3/27/2014]. Moskovskiy ekonomicheskoy forum [The Moscow Economic Forum]. Available at: http://me-forum.ru/ media/news/2413/ (date of access: 20.04.2014). 
3. Atkin, R. H. (1997). Combinatorial Connectivies in Social Systems. An Application of Simplicial Complex Structures to the Study of Large Organisations. Interdisciplinary Systems Research, 493-498.

4. Axelrod, R. (1976). The Structure of Decision: Cognitive Maps of Political Elites. Princeton. University Press, 405.

5. Eden, C. (1998). Cognitive mapping. European Journal of Operational Research, 36, 1- 13.

6. Legrand, J. (2010). How far can Q-analysis go into social systems understanding? Res-Systemica, 11. Available at: http:// www.afscet.asso.fr/resSystemica/Crete02/Legrand.pdf (date of access: 20.04.2014).

7. Warren, K. (2008). Strategic Management Dynamics. John Wiley\&Sons.

8. Verba, V. A. (2011). Modeli prinyatiya resheniy v slabostrukturirovannykh sistemakh regionalnoy ekonomiki [Decisionmaking model in semi-systems of the regional economy]. Ekonomicheskiy analiz: teoriya i praktika [Economic Analysis: Theory and Practice], 22, 56-64.

9. Gorelova, G. V. (2013). Kognitivnyy podkhod k imitatsionnomu modelirovaniyu slozhnykh system [Cognitive approach to the simulation of complex systems]. Izvestiya Yuzhnogo federalnogo universiteta. Tekhnicheskie nauki [Proceedings of the Southern Federal University. Engineering], 3 (140), 239-250.

10. Kakatunova, T. V. \& Zhuzhgina, I. A. (2013). Metodika postroyeniya kognitivnoy modeli regionalnoy inovatssionnoy sistemy. [The method of constructing the cognitive model of regional innovation system]. Vestink Rossiyskoy akademii estestvennykh nauk [Bulletin of the Russian Academy of Natural Sciences], 17(2), 34-36.

11. Kochkarov, A. A. \& Salpagarov, M. B. (2006). Kognitivnoye modelirovanie regionalnykh sotsialno-ekonomicheskikh system [Cognitive modeling of regional socio-economic systems]. Upravlenie bolshimi sistemammi [Managing large systems], 16, 137-145.

12. Kulba, V. V., Kononov, D. A., Kovalevskiy, S. S., Kosyachenko, S. A., Nizhegorodtsev, R. M. \& Chernov, I. V. (2002). Stsenarnyy analiz dinamiki povedeniya sotsialno-ekonomicheskikh system (Nauchnoye izdanie) [Scenario analysis of the dynamic behavior of socio-economic systems. (Scientific edition)]. Moscow, IPU RAN [Institute of Control Sciences, Russian Academy of Sciences], 122.

13. Sirazetdinov, T. K., Rodionov, V. V. \& Sirazetdinov, R. T. (2005). Dinamicheskoye modelirovanie ekonomiki regiona [Dynamic modeling of the regional economy]. Kazan, Izd-vo "Fen" Akademii nauk RT ["Feng" Publ. of the Academy of Sciences], 320.

14. Maslennikova, A. V. (2008). Issledovanie sotsialno-ekologo-ekonomicheskogo potentsiala regionalnoy sistemy dlya realizatsii strategii ustoychivogo razvitiya [Study of the socio-ecological and economic potential of a regional system for the implementation of sustainable development strategies]. Vestnik Rostovskogo gosudarstvennogo universiteta putey i soobshcheniy [Bulletin of the Rostov State University of Railways], 4, 95-101.

15. Gorelova, G. V., Zakharova, Ye. N. \& Radchenko, S. A. (2006). Issledovanie slabostrukturirovannykh problem sotsialnoekonomicheskikh system: kognitivnyy podkhod [Study of semistructured problems of socio- economic systems: the cognitive approach]. Rostov-on-Don, Izd-vo RGU [RSU Publ.], 332.

16. Gorelova, G. V. \& Melnik, E. V. (2011). O kognitivnom modelirovanii razvitiya situatiy v regione v usloviyakh bystrykh izmeneniy sredy i protivodeystviyakh [About cognitive modeling of development in the region in terms of rapid changes in the environment and countering]. Izvestiya YuFU. Tekhnicheskie nauki [News of SFU. Engeneering], Vol. 116, 3, 65-78.

\section{Information about the authors}

Matveyeva Lyudmila Grigoryevna (Rostov-on-Don, Russia) - Doctor of Economics, Professor, Head of Department of Information Economy, Southern Federal University (105/42, B. Sadovaya, Rostov-on-Don, 344006, e-mail: matveeva_lg@mail.ru).

Mikhalkina Yelena Vladimirovna (Rostov-on-Don, Russia) - Doctor of Economics, Professor, Head of Department of Human Resource Management, Southern Federal University (105/42, B. Sadovaya, Rostov-on-Don, 344006, e-mail: mikhalkina_e@mail.ru).

Chernova Olga Anatolyevna (Rostov-on-Don, Russia) - Doctor of Economics, Associate Professor, Department of Information Economy, Southern Federal University (105/42, B. Sadovaya, Rostov-on-Don, 344006, e-mail: chernova.olga71@yandex.ru). 